\title{
CORRESPONDENCE
}

\section{Swiss vote did not decide disposal issue}

SIR, - In the issue of $27 \mathrm{March}$, page 294, under the heading "Power dissenters through Europe", was a report on an anti-test drilling vote in the Swiss village of Hägendorf. The assertion that this vote "may have blocked effectively further nuclear development in Switzerland" is unfounded and should be corrected.

The cooperative Nagra has been charged by the Swiss government and the utilities with nuclear power plants, with working out a national disposal concept by 1985 , and test drillings are an integral part of the project plans. Hägendorf is one of 12 sites in northeast Switzerland for which drilling applications will soon be submitted.

Because nuclear waste disposal is recognized to be a national issue, it was clearly specified in the revised nuclear law accepted by the Swiss public in 1979 that the government is directly responsible for decisions on disposal questions. This responsibility includes any preparatory investigatory work such as the proposed test drillings.

The vote in Hägendorf was of a consultative nature. This implies that the government will take such indications of local opinion into account as far as possible, but must also consider the broader, national issues involved. While the applications are being considered project work on waste disposal is continuing on a broad front including planning of further drilling in geological formations other than the deep crystalline rocks currently being investigated.

Yours faithfully,

H. ISSLER C. MCCOMBIE Nationale Genossenschaft für die Lagerung Radioaktiver Abfalle, Baden, Switzerland

\section{UK science budget: now the bad news}

SIR,-Your report (3 April, page 391) that the science budget will be relatively stable for the next four years misses one important point. Less than half the funds of the Agricultural Research Council comes from the science budget; the majority comes from the Ministry of Agriculture, Fisheries and Food. This has been cut for $1980 / 1$ by an average of $6 \%$ but some research institutes will, at constant value, have lost $15 \%$ of their $1979 / 80$ budget level by $1981 / 2$. There is no promise of stability for this funding and our fear is that it will decrease further.

I am not out, at least on this occasion, to indulge in special pleading on behalf of agricultural research, or for research in general. It is important, however, that you and your readers are aware that for at least one of the research councils the outlook is neither as good nor as stable as you implied. Yours faithfully,

JOHN GOODIER

Agricultural Research Council, London

\section{Genothetically speaking}

SIR, - The use of new techniques in molecular biology has allowed the fragmentation of the genome of an organism and the introduction of its pieces into adequate hosts where the entire genome can be stored for the desired use when required. This collection of genes is termed in the laboratory jargon and also in the specialized literature "a library of genes". Library is defined in several English dictionaries both British and American as "a place set apart to contain books for reading, study or reference; a collection of books, especially one for use by the public" Therefore it seems that the expression "library of genes" is inadequate. (This fact becomes more obvious taking into account that library is specifically derived from the Latin word for book, liber.

The discovery of new phenomena or the introduction of new concepts may need the introduction of new words to characterize them precisely. I feel that in the case mentioned above the creation of a new word is fully justified. I would like to propose the word genotheque to designate the collection of genes of an organism introduced into an appropriate host species. This short word is derived from gene and the greek root $\theta \eta \times n$ (box). This last root appears with the same meaning as that proposed in several English scientific words (perithecium, spermatheca) and in other languages in the word for library (biblioteca, bibliotheque, Bibliothek.)

If we have discotheque, why not genotheque?

Yours faithfully, Carlos Gancedo

Instituto de Enzimologia del CSIC Facultad de Medicina. Universidad Autónoma, Madrid-34, Spain

\section{Ke Xue not pucka}

SIR,-In his letter (3 April, page 394) Gerard Piel disputed with my statement in a recent Nature article that "There are no cover-tocover translations into Chinese" of foreign scientific journals as yet, by pointing to $K e$ $X u e$ which is the Chinese edition of Scientific American being circulated in China. It needs however, to be clarified that this magazine is not regarded by the Chinese as belonging to the category of primary journals, which was the object under examination in my article. Another reason why I did not mention $\mathrm{Ke} X u e$ was that its publication is a joint exercise and not a solely Chinese effort.

Yours faithfully,

Darwin College, Cambridge

T. B. TANG

\section{Wallis's biblical gesture}

SIR, - In Kings Norton's obituary (20 March, page 288) of Sir Barnes Wallis, he mentions that Wallis presented his $£ 10,000$ award for his wartime dambusting bomb to a charitable foundation (to help educate the sons and daughters of men who died serving with the RAF). Why he did this deserves to be known. In the book The Dam Busters, Paul Brickhill relates the tremendous effort expended for the German dams' raid. When it was radioed by 617 squadron that the Mohne and Eder dams were breached, Sir Wallis was ecstatic that the huge work succeeded. Afterwards, though, he learned that $50 \%$ of the attacking planes were lost with the death of 53 very young men. He was shocked and saddened, and said "Oh, if I'd only known, I'd never have started this!" Many years later he was presented the above award. When Paul Brickhill asked him why he gave it away, he replied: "My dear chap, go and read your Bible, turn up Samuel II, Chapter 23. You probably haven't a Bible, so I'll tell you this story about David.

"He was hiding in the cave of Adullam after the Philistines had seized Bethlehem, and in his anguish he said, ' $O$ that one would give me a drink of water of the well of Bethlehem, which is by the gate!' Now the three mighty men who were his lieutenants were with him, and I'm dashed if they didn't fight their way through the Philistine lines and draw a goatskin of water out of the well by the gate.

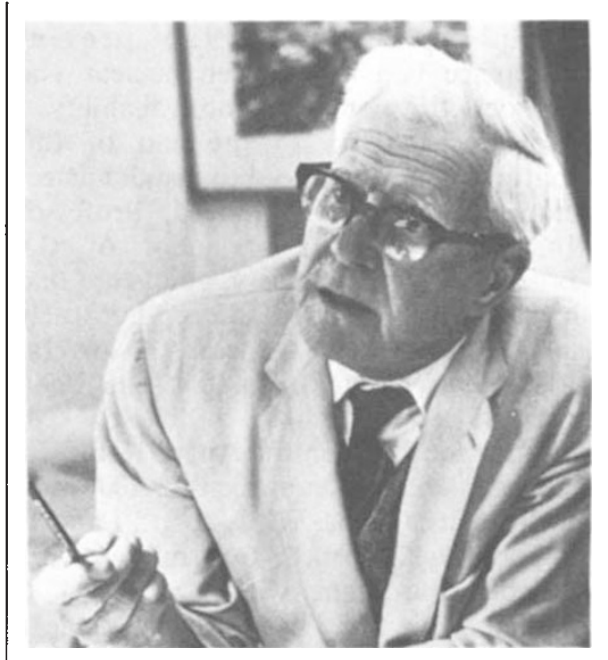

They fought their way back and took the water to David in the cave, but when they told him how they had got it, he would not drink it. They asked him why, and he said: 'Is not this the blood of the men that went in jeopardy of their lives?"'

Yours faithfully,

University of Texas, Austin, US

P. D. MORLEY

\section{Optical effects in taxis}

SIR, - I wonder if any of your readers can explain a strange optical perception effect I've noticed when travelling in a London taxi-cab? No-one I've described it to has a simple explanation; and I assure you it is not restricted to trips taken after alcoholic lunches. The effect is most visible at night.

London taxis, like many others, have a vertical glass partition between the passenger seats, which face forwards, and the driver. Behind the passenger is the rear window of the cab, through which can be seen the receding road, street lights, other vehicles and buildings.

The glass partition acts like a partial mirror; in it one sees a reflection of the view through the rear window, and through it the back of the driver, the meter, and part of the view through the front cab window.

The effect - and when one has spotted it it is quite marked - is that the objects reflected in the partition glass (ie those in the view through the rear window) appear to be receding very fast, much faster than the cab is apparently travelling judging by the view forward through the partition. Subjectively, the impression is of about twice the cab's real speed. I first noticed it with the reflection of traffic lights receding at night as the cab passed them.

The effect disappears completely if one turns around and looks directly out of the rear window; there one's perception is roughly as expected. Turning back to the reflection of the same view, the recession seems to speed up again

The only explanation I can think of is that the fixed angular size of most of the throughscreen images (the back of the driver, the cab) and the increasing angular size of others (the road forward) provides a reference frame against which the decreasing angular size of the reflection is correctly perceived. Turning around, the frame of the window is too peripheral to provide an effective reference, and the brain's mechanisms for maintaining a constant perception of size of an object despite its distance come into play. Is this a possibility? Yours faithfully,

ROBERT WaLgate

20, Roy Road, Northwood, Midddlesex 